\title{
USE OF MOBILE DEVICES FOR HEALTH CARE INFORMATION BY POST GRADUATE PHYSIOTHERAPY STUDENTS
}

\author{
Shivani Verma *1, Megha Sheth ${ }^{2}$. \\ ${ }^{* 1}$ Post graduate student, SBB college of physiotherapy, Ahmedabad, Gujarat, India. \\ ${ }^{2}$ Lecturer, SBB college of Physiotherapy, Ahmedabad, Gujarat, India.
}

\section{ABSTRACT}

Background: The availability and use of electronic devices among the students of higher education have been continuing to grow. The devices connect the users to the world instantly, allow access to information, and enable interactivity with others. The uses of these devices like E-book reader, Personal Digital Assistant or tablet/iPad are playing an important role, especially in their academic lives. This survey aimed to find the commonly used mobile devices among post graduate physiotherapy students, their purpose of use and the modes of obtaining health-care information along with the barriers they face during this.

Methodology: A cross sectional survey study was conducted for which a questionnaire was designed based on studies done about use of mobile-devices among health care providers. Convenience sampling was used and the questionnaire was distributed among 70 post graduate physiotherapy students of various physiotherapy colleges of Gujarat.

Result: It was found that among the post graduate students $52 \%$ students used their cell phones as a choice of mobile device.1\% students used tablets for their data collection of research studies. Cell phones were mostly used for WhatsApp (61\%) and Facebook, (30\%). 51\% used mobile devices more than once a day to access medical resources. $71 \%$ used mobile devices to search for journals and articles while $70 \%$ use it for finding information about physiotherapy techniques. 65\% preferred using Google scholar as a source of medical information.

Conclusion: Cell phones are the commonly used mobile devices among post graduate physiotherapy students. Moreover, there is lack of awareness among them about the resources available. There is a need to increase awareness regarding Handheld computers which are becoming an important part of patient care and documentation through electronic order entry and patient tracking applications and also about Mobile health ( $\mathrm{m}$-health).

KEY WORDS: Mobile devices, Cell Phones, Physiotherapy, Applications.

Address for correspondence: Shivani Verma, Post graduate student, SBB college of physiotherapy, Ahmedabad, Gujarat, India. E-Mail: shivaniverma2288@gmail.com

\begin{tabular}{|c|c|c|c|}
\hline Access this Article online & \multicolumn{3}{|c|}{ Journal Information } \\
\hline \multirow[t]{5}{*}{ Quick Response code } & \multirow{2}{*}{\multicolumn{3}{|c|}{$\begin{array}{l}\text { International Journal of Physiotherapy and Research } \\
\text { for 2016 ISSN (E) 2321-1822 | ISSN (P) 2321-8975 }\end{array}$}} \\
\hline & & & \\
\hline & $\begin{array}{l}\text { https://w } \\
\text { DOI-Prefix: htt| }\end{array}$ & $\begin{array}{l}\text { nr.org/jpp.rntmi } \\
\text { doi.org/10.16965/ijpr }\end{array}$ & $(\mathrm{cc})^{\mathrm{E}}$ \\
\hline & \multicolumn{3}{|c|}{ Article Information } \\
\hline & $\begin{array}{l}\text { Received: } 31 \text { Jul } 2018 \\
\text { Peer Review: } 31 \text { Jul } 2018\end{array}$ & $\begin{array}{l}\text { Accepted: } 06 \text { Sep } \\
\text { Published (0): } 01\end{array}$ & 8 \\
\hline DOI: 10.16965/ijpr.2018.173 & Revised: None & Published (P): 11 & 2018 \\
\hline
\end{tabular}

\section{INTRODUCTION}

The past decade has witnessed the advent of smartphone, a device armed with computing power, mobility and downloadable "apps". Since then mobile devices (personal digital assistants, smartphones, and tablet computers) have been widely adopted by health care professionals $[1,2]$. These devices are quickly becoming one of the main tools for accessing clinical information, especially for younger health professionals and trainees. Many medical resources of varying quality are available for these devices. Some are free and others need to be purchased which not many students prefer $[3,4]$.

The general trend towards increased smart phone and applications use has penetrated the 
medical and paramedical community. The increased popularity of apps among health care providers resulted in a dedicated medical app category created in the apple app store in 2008 [5]. Various websites have also emerged devoted entirely to reviewing apps designed specifically for physicians [6]. Till now no such specific app use has been recorded for physiotherapy in developing nations. Very few studies have highlighted the successful use of mobile phones to support telemedicine and remote healthcare in third world countries.

The aim of the present study was to find:

1. The widely used mobile device by physiotherapy students in Gujarat

2. The attitude of students towards mobile devices, apps and their use.

3. The obstacles that one faces while using mobile devices for health care information.

\section{METHODOLOGY}

A cross sectional survey study was conducted for which a questionnaire was designed based on studies done about use of mobile-devices among health care providers [2-5]. Questions from previous questionnaires were adapted according to the present population. The adapted questionnaire was then given to 5 senior therapists for expert opinion and 2 modifications were made. 5 students were also asked for suggestions, no changes were made. This questionnaire was then used in the study. Convenience sampling was used and the questionnaire was distributed among 70 post graduate physiotherapy students. These students belonged to 5 physiotherapy colleges of Gujarat and were ready to participate.

\section{RESULT}

All 70 subjects completed the survey. Fortyseven were first year post graduate students and 23 were second year students. 3 were males and 67 females. Mean age of the subjects was 23 years. $52 \%$ students used their cell phones as a first choice of mobile device as compared to laptop which $32 \%$ population used as their first choice. Very few post graduate physiotherapy students preferred E-book reader, Personal Digital Assistant or tablet/ipad.1\% students used tablets for their data collection of research studies. Cell phones were mostly used for whatsapp (61\%) and Facebook, (30\%). 51\% used mobile devices more than once a day to access medical resources. $71 \%$ used mobile devices to search for journals and articles while $70 \%$ use it for finding information about physiotherapy techniques. $47 \%$ students used it for performing clinical calculations like BMI. 34\% used it for taking notes, $52 \%$ used it for finding lecture specific information, $48 \%$ used mobile devices to find meaning of a new term and $24 \%$ read e-books on their mobile devices. $65 \%$ preferred using Google scholar as a source of medical information and not many liked to use Medscape, pubmed, Physiopedia. None of the students had purchased any medical apps or resources. Results are presented in Graph 1 and 2.

Graph 1: Resources used for retrieving information.

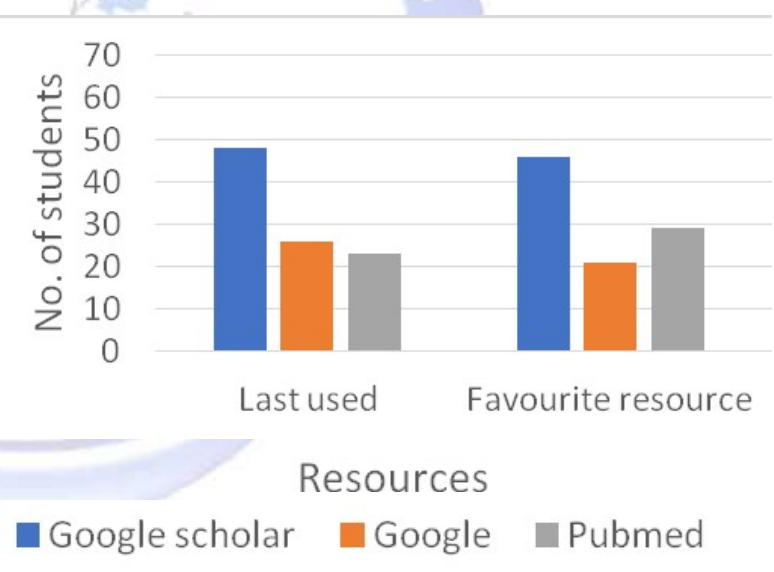

Graph 2: Barriers faced by students while assessing resources on mobile devices.

\section{No. of students}

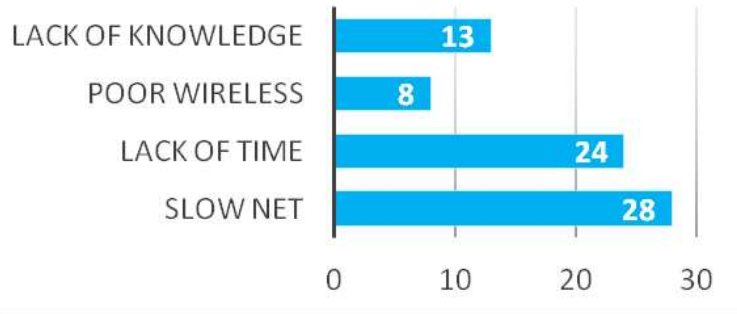

$40 \%$ considered slow internet speed as a barrier to assess medical information on mobile phones and $34 \%$ thought lack of time as a barrier. $18 \%$ of first year post graduate students considered lack of knowledge about use of mobile devices and $14.2 \%$ did not understand 
the resources and availability of the resources.

\section{DISCUSSION}

This study found that respondents used a number of electronic devices, this has also been observed among the US health-care professionals and four Canadian university students [7-9]. The study showed $52 \%$ used cell phones while others did use other mobile devices like laptops, tablets and personal digital assistant.

Similar to the present study, the use of smartphones has been in much increase among medical and paramedical professionals from India and the United States including students, especially for retrieving articles and books and for clinical evidence $[10,11]$.

The University of Leeds [12] lends iphones to all year-III and -IV medical students while Stanford University [13] provides ipads to all the medical students. This is to promote among the professionals and the students the innovative roles of the electronic in the field of internal medicine, which includes patient care, continuing education, communication, and research.

Multiple studies have reported that handheld electronic gadgets were regularly used by the medical students, medical lecturers, and house officers to obtain references and necessary information for diagnosis and prescription [1416]. In the present study $56.7 \%$ students used mobile devices for finding lecture specific information which could be due to the academic inclination.

It has been reported that, before the development and marketing of iphone, medical students and faculties were using "specific clinical apps" to resolve any practical hurdles in managing patients [4]. This trend though hasn't been found in the present study, as only $2 \%$ of students are using specific apps for healthcare information or research purpose.

A survey showed the 10 most frequently mentioned favourite resources were: uptodate (18.9\%), Epocrates and Medscape/emedicine (tied at $11.5 \%)$, Lexicomp (10.3\%), pubmed (6.9\%) [17]. While in the present study Google scholar was the default search option (33.6\%), pubmed was preferred by comparatively less students.(10\%).
A Canadian survey had reported that $54 \%$ students purchased medical apps or resources [17] whereas according to the present study done on Indian students, none of them had purchased any medical apps or resources.

Most students and professionals face the barriers of slow loading times, intermittent internet connections, and inability to access needed information as a result. Some face the problem fact that many medical sites are not modified to be compatible with iPhone $[17,18]$. In the current study $40 \%$ considered slow internet speed as a barrier to assess medical information on mobile phones and $34 \%$ thought lack of time as a barrier. $18 \%$ of first year post graduate students considered lack of knowledge about use of mobile devices and $14 \%$ did not understand the resources and availability of the resources. Qualitative comments showed lack of interest and too much information for a single topic and moreover most good articles aren't free of cost to be the barrier for the students.'

The limitation of the present study is answers could have been biased as it was a self-administered questionnaire. Duration of use of mobile device each day was not taken into consideration and the availability of mobile data was not assessed.

\section{CONCLUSION}

Cell phones are the commonly used mobile devices among post graduate physiotherapy students which they used for social networking and for their research work. Google scholar is the most used resource for assessing healthcare information. There is a need to increase knowledge regarding resources available in form of applications or websites, their use and about Mobile health (m-health).

\section{Conflicts of interest: None}

\section{REFERENCES}

[1]. Burnette P. Mobile technology and medical libraries:worlds collide. Ref Lib. 2011;52(1-2):98105.

[2]. Garritty C, El Emam K. Who's using pdas? Estimates of PDA use by health care providers: a systematic review of surveys. J Med Internet Res. 2006 AprJun;8(2):e7. 
[3]. Leon SA, Fontelo P, Green L, Ackerman M, Liu F.Evidencebased medicine among internal medicine residents in a community hospital program using smartphones. BMC Med Inform Decis Mak. 2007 Feb 21;7:5.

[4]. Chatterley T, Chojecki D. Personal digital assistant usage among undergraduate medical students: exploring trends,barriers, and the advent of smartphones. J Med Lib Assoc. 2010 Apr;98(2):15760.

[5]. Dolan, B., Timeline: Medical milestones for the iphone. Mobi Health News. Http://mobihealthnews .com/11290/timeline-medicalmilestones- for-theiphone/. Accessed August 22011.

[6]. Franko, O. I., Smartphone apps for orthopaedic surgeons. Clinorthop Relat Res 2011;469(7):20422048.

[7]. Ventola CL. Mobile devices and apps for health care professionals:uses and benefits. $P \mathrm{~T}$. 2014;39(5):356-64.

[8]. Prgomet M, Georgiou A, Westbrook JI. The impact of mobilehandheld technology on hospital physicians' work practices and patient care: a systematic review. J Am Med Inform Assoc. 2009;16(6):792-801.

[9]. Wu RC, Morra D, Quan S, Lai S, Zanjani S, Abrams H, et al. The useof smartphones for clinical communication on internal medicinewards. J Hosp Med. 2010;5(9):553-9.

[10]. Chatterley T, Chojecki D. Personal digital assistant usage among undergraduate medical students: exploring trends, barriers, and the advent of smartphones. J Med Libr Assoc. 2010;98(2):157-60.

[11]. Bala A, Gupta BM. Perceptions of health professionals regardinguse and provision of LIS through mobile technologies. DESIDOC jlib Inf Technol. 2010;30(3):7-12.
[12]. Bushhousen E, Norton HF, Butson LC, Auten B, Jesano $R$, David $D$,et al. Smartphone use at a university health science center. Med refserv Q. 2013;32(1):5272.

[13]. Boyce N, Sandheep Sugathan,Osman Ali. Use of electronic devices by the medical students of uniklRCMP, Malaysia, and its inûuence on academic performances. Lancet. 2012;379:209.

[14]. Ozdalga E, Ozdalga A, Ahuja N. The smartphone in medicine:a review of current and potential use among physicians and students. J Med Internet Res. 2012;14(5):e128.

[15]. Franko OI, Tirrell TF. Smartphone app use among medical providers in ACGME training programs. J Med Syst. 2012;36(5):3135-9.

[16]. Payne KF, Wharrad H, Watts K. Smartphone and medical related App use among medical students and junior doctors in the United Kingdom (UK): a regional survey. BMC Med Inform Decis Mak.2012;12:121.

[17]. Wallace S, Clark M, White J. 'It's on my iphone': attitudes to the use of mobile computing devices in medical education, a mixed methods study BMJ Open. 2012;242(4):ii-e00109.

[18]. Jill T.Mobile devices in medicine- a survey. J Med Lib Assoc 2014;102(1).

[19].Karim, Nor Shahriza Abdul; Darus, Siti Hawa \& Hussin, Ramlah. Mobile phone applications in academic library services: A students' feedback survey. Campus-Wide Inform. Syst. 2006;23(1):35-51.

$$
\begin{aligned}
& \text { How to cite this article: } \\
& \text { Shivani Verma, Megha Sheth. USE OF MOBILE DEVICES FOR HEALTH CARE } \\
& \text { INFORMATION BY POST GRADUATE PHYSIOTHERAPY STUDENTS. } \\
& \text { Int J Physiother Res 2018;6(6):2905-2908. DOI: 10.16965/ijpr.2018.173 }
\end{aligned}
$$

